\title{
SUSTAINABLE SHRIMP FISHERIES MANAGEMENT AT SORONG SELATAN OF WEST PAPUA USING EAFM TOOLS IN FISHING DOMAIN TECHNIQUES
}

\author{
Ratna*, Fahrizal Ahmad, Badarudin M. Iksan \\ University of Muhammadiyah, Sorong, Indonesia \\ Razak Abu Darda, Suruwaky Amir \\ Politeknik KP, Sorong, Indonesia \\ Irwanto \\ WWF Indonesia / USAID SEA Project \\ *E-mail: ratnathoria@gmail.com
}

\begin{abstract}
The purpose of this study is to determine the status of the ecosystem approach to fisheries management (EAFM) in the Fishing Technique Domain for shrimp commodities in South Sorong Regency. This research was conducted in September 2018 and took place in the South Sorong Regency of West Papua Province precisely in Teminabuan District, Konda District, and Inanwatan District. The data collection technique used in this study is observation where the researchers conducted a direct observation of the object of the research to see the activities in the area closely. From the results of the study, the analysis of EAFM composite index in the domain of fishing technique in South Sorong Regency showed that destructive fishing for banana shrimp (Penaeus merguiensis) is in good condition with a green modeling flag and an average value of 3 . In this study, the indicators of fishing gear and fishing aids modification, the indicators of fisheries capacity and fishing efforts, as well as capture selectivity are in good status. Whereas, the indicators that have bad status and need to be prioritized for future sustainable fisheries management are fishing with legal documents and fishing vessel crew certificates.
\end{abstract}

\section{KEY WORDS}

Management status, fishing technique domain, EAFM.

Indonesia is one of the largest maritime and archipelagic countries in the world. This country is located in the tropics with a coastline length of $81,000 \mathrm{~km}, 18.4 \%$ of the 440,000 $\mathrm{km}$ long coastline of the world. The diversity of biological resources including fish resources in Indonesia is very high. Indonesian waters have $27.2 \%$ of the world flora and fauna species, including 12\% mammals, 23.8\% amphibians, $31.8 \%$ reptiles, $44.7 \%$ fish, $40 \%$ mollusks, and $8.6 \%$ seaweed. From this potential, it is shown that fish resources have the highest percentage. Indonesia has the largest potential of fisheries in the world that around 65 million tons of the potential has not been utilized optimally. It can be said that Indonesia only explored $20 \%$ of the resources (Dahuri, 2013).

The maritime and fisheries sector is one of the strategic choices to be developed, especially in Eastern Indonesia. The east area of Indonesia has great potential but has not been utilized optimally. Fisheries management is obligatory as mandated by (Law number 31,2004 ) and reaffirmed in the amendment (Law number 45, 2009). Under the Law, fisheries management is defined as all efforts which cover integrated processes in information gathering, analysis, planning, consultation, decision making, and allocation of fish resources as well as the implementation and law enforcement in the fisheries sector carried out by the government or other authorities aimed to achieve the continuity in productivity of aquatic biological resources and agreed objectives.

Besides providing income benefits to the community and the country, fisheries resource management also causes some problems in the form of excessive catching and 
habitat damage. Both of these problems arise due to the increase in the human population that requires food ingredients and the advancement in equipment capacity which leads to unsustainable fishing practices that cause fisheries production to decline both on a local, national, and global scale. Overfishing will decrease reproductive capacity and stock recovery capacity (Ali, 2012). Fisheries management plays an important role in realizing sustainable fisheries, especially for important fishery commodities such as shrimp. One of the shrimp producing areas in Indonesia is South Sorong Regency (Razak, Fahrizal, \& Irwanto, 2018)

South Sorong Regency is a region which produces penaeid shrimp, one of the leading commodities in the region. The penaeid shrimp are captured using a trammel net. The use of trammel net as fishing gear needs to be studied so that it can be utilized continuously. The fishermen in the region keep increasing the fishing efforts to achieve maximum catch because of the high demand for shrimp. Although marine biological resources are renewable resources, the balance of the aquatic biological environment and the ability to recover will be disrupted if the fishing effort exceeds its carrying capacity (Sururi, Mustasim, Hoek, \& Anasri, 2017). In order to maintain its sustainability, its utilization and management must be carried out rationally.

One approach that can make fisheries management better is an ecosystem approach to fisheries management (EAFM). EAFM has been identified as a fairly successful fisheries management compared to other fisheries management. It is expected that the ecosystembased fisheries management can give more attention to the environment and fish resources without threatening the economic sector and social sector (Adrianto, et al., 2014). Therefore, the importance of knowing sustainable fishing techniques will determine the sustainability of fisheries both in terms of its ecology and economics. This becomes the background of the author to conduct a study entitled "Sustainable Shrimp Fisheries Management in Sorong Selatan, West Papua Using Eafm Tools in Fishing Domain Techniques".

\section{METHODS OF RESEARCH}

This research was conducted in September 2018 and took place in the South Sorong Regency of West Papua Province precisely in Teminabuan District, Konda District, and Inanwatan District.

The tools and materials in this research were: stationery, cameras, lapboard, recorder, shrimp, and questionnaires.

The method in this research was direct observation to take a closer look at the activities carried out (Riduwan, 2004) as well as an interview with questions to obtain information directly to the respondents. The interviews were performed verbally and face to face between interviewer and respondents (Subagyo, 2011).

The research procedure was done by conducting interviews with respondents located in Teminabuan District, Konda District, and Inanwatan District for one to two weeks.

The analysis of the data used in this study was the Flag Modeling Analysis and Descriptive Analysis. Flag Modeling analysis was carried out by using a multi-criteria analysis (MCA) approach where a set of criteria is built as a basis to analyze the performance of fisheries management region viewed from the ecosystem approach to fisheries management (EAFM) through the development of composite indices (Adrianto, Matsuda, and Sakuma, 2005) with the following stages:

- Determining the criteria for each indicator in each EAFM Domain;

- Giving a score on each indicator using Ordinal-based Likert Score 1, 2, 3;

- Determining the weight for each indicator.

The value of each indicator in the Fishing Technique Domain was analyzed using a simple arithmetic-based composite analysis. The value is displayed in the form of flag model in the following Table 1.

According to (Nazir, 2005), descriptive analysis is a method of examining the status of a group of humans, objects, sets of conditions, systems of thought, or a class of events in the present. Descriptive analysis aims to make a description, illustration, or painting 
systematically, factually, and accurately about the facts and the relationship between the phenomena studied. This analysis is used to explain the status of fisheries management in South Sorong Regency and discuss the results of the EAFM assessment.

Table 1 - The Classification of Composite Index Values and Flag Model Visualization

\begin{tabular}{|c|c|c|}
\hline Score & Flag Model & Description \\
\hline 1 & & Bad \\
\hline 2 & & Moderate \\
\hline 3 & & Good \\
\hline
\end{tabular}

Source: (Adrianto, et al., 2014).

\section{RESULTS AND DISCUSSION}

The domain of fishing technique consists of six indicators that explain the management of shrimp resources, especially banana shrimp or white shrimp (Penaeus merguiensis) in South Sorong Regency from the aspect of fishing techniques. The six indicators are:

The indicators of destructive fishing can be seen from the use of fishing tools and methods that could damage the environment and/or do not comply with the applicable regulations. This destructive and/or illegal fishing includes: the use of hazardous materials and/or tools (such as: fish bombs, cyanide poisons, potassium, and electricity) and the use of fishing gear that does not comply with applicable regulations (such as: the operation of fishing gear in the protected habitat or not on the legal fishing lane/area).

The purpose of using this indicator is to identify the impact of fishing gear and fishing aids modification that is not in accordance with the regulation of fish resources preservations in particular water area. The fishing technique domain has the biggest value in the indicators of destructive and/or illegal fishing methods.

Based on the results of interviews with the Department of Marine and Fisheries and Marine Police of South Sorong Regency, there are no written reports regarding violations. Whereas, based on the results of interviews with the stakeholders or fishermen (Head of Village, Coordinator of Fishermen, Head of Watershed, and Tribal Chief) there are violations such as the use of bore roots and the occurrence of Endangered, Threatened, and Protected (ETP) species including turtles, saw sharks, and dolphins. The results of the assessment on destructive fishing methods show a value of 3 which means that the frequency of violations is $<5$ cases per year.

The modification of fishing gear and fishing aids is defined as the use of fishing gear and fishing aids that is not in accordance with the regulations and can cause a negative impact on fish resources.

Based on the results of interviews and direct observations in the field, no modifications are found to the construction of fishing gear such as the use of smaller webs than the applicable provisions because fishermen in the three districts do not have the expertise to modify their fishing gear. Therefore, the fishermen used standard fishing gear from the factory.

Whereas, to determine fishing ground, fishermen do not use fishing aids but by lowering the net to the bottom. If there are several shrimps, the fishermen will start their fishing operations in the area, but if there is no shrimp found, the fishermen will move to another location. Based on the description above, the indicator of fishing gear and fishing aids modification has a score of 3 . This means that $<25 \%$ of the target species has a size of $<$ Lm.

Fishing capacity is defined as the maximum number of fish catches that can be produced in a certain period of time (years) by a ship or fishing vessels when fully operated, where the efforts and catches are not blocked by various fisheries management actions. The units used for fishing capacity are tons/year. Fishing capacity is calculated based on ship characteristics. The indicator that is widely used is the tonnage of a ship that shows the strength of the ship and the engine power used. In addition to the tonnage and strength, fishing gear is also often used as an indicator of fishing capacity. 
Based on the Baseline Survey Report (2017) and USAID SEA Project (2018), the ratio of catching capacity is $>1$ with a value of 3 (good).

Capture selectivity is defined as fishing activities that are associated with the area, time, and a variety of catches. The criteria for evaluating the good or bad indicators of capture selectivity in fisheries management with an EAFM is by calculating the percentage of fishing gear which is classified as not or less selective for the total number of fishing gear in a particular water area.

Based on the Decree of the Minister of Maritime Affairs and Fisheries number 54 of 2014, a catch is classified as high selectivity if it has: fishhook; gill nets; clam collector; lift nets (boat chart, step chart), purse seine, and trap (Sero, Bubu). Meanwhile, low selectivity fishing gear is trawl (shrimp trawler, fish trawler); trawl bag (lampara, beach trawl); and muroami.

The type of fishing gear used by fishermen in South Sorong Regency is Trammel Net. Based on the criteria of environmentally-friendly fishing gear according to the Regulation of the Minister of Marine and Fisheries number 12 of 2012), the type of fishing gear operated by fishermen in South Sorong Regency is environmentally friendly because it does not destroy the habitat of the fish. The catching activity is associated with the area, time, and variety of catches. The selectivity of fishing gear is the ability of fishing gear to select the type and size of a particular catch. Thus, the capture selectivity in South Sorong Regency is 3 (high, less than $50 \%$ ). In other words, the fishermen use fishing gear that is not selective by $>31 \%$ of the total catches (Razak, Fahrizal, \& Irwanto, 2018).

The function and size of fishing vessels for fishing operations need to have legal documents. Based on the observations, the types of fishing vessels used by fishermen in carrying out fishing activities are rowing boats, motor boats/Jhonson $<3$ GT, and Jolor boats.

Based on the results of interviews with fishermen, it is found that all fishermen who conducted fishing operations do not have legal documents because all of them owned boats under the 3GT so that they did not have a fishing permit or other letters.

The interviews also show that there is no policy from the Department of Marine and Fisheries of South Sorong Regency regarding the compliance of function and size of ships or boats with the documents owned by each fisherman. Based on the above description, the score for the indicators of the compliance of function and size of fishing vessels with legal documents is 1 (low). This means that more than $50 \%$ of the samples are not in accordance with legal documents.

The certification of fishing vessel crews that are in accordance with the regulations can be defined as fishing vessel crews who have fulfilled certain skill requirements to work on a ship. The certification is carried out to establish a responsible fishing activity for fishing vessel crews. The purpose of using this indicator is to estimate the percentage rate of samples of fishing vessels operated by certified crews and to estimate the application of responsible fishing activities in certain watersheds (KKP, 2017).

The fishing certificates are very difficult to get because the fishermen in the three districts generally work on $<5$ GT boats for the shrimp fishing activities. Therefore, they do not have the certificates because they are traditional fishermen.

As for the fishing operations, they usually do it based on the skills/experience only. They do not have certificates so that the score will be 1 (certificate ownership is less than $50 \%)$.

Table 2 - The Analysis of Flag Model on Six Fishing Technique Domain Indicators

\begin{tabular}{|l|c|}
\hline \multicolumn{1}{|c|}{ Indicators } & Score \\
\hline 1. Destructive fishing & 3.00 \\
\hline 2. Fishing gear and fishing aids modification & 3.00 \\
\hline 3. Fishing capacity and effort & 3.00 \\
\hline 4. Capture selectivity & 3.00 \\
\hline 5. The compliance of the function and size of fishing vessels with legal documents & 1.00 \\
\hline 6. The certification of fishing vessel crews based on the regulations. & 1.00 \\
\hline \multicolumn{1}{|c|}{ Average } & 2.33 \\
\hline
\end{tabular}


The results of the assessment on the fishing technique domain indicate that the management of banana shrimp (Penaeus merguiensis) commodities is in a good condition with an average value of 3 because there are no destructive or illegal fishing activities. The results of the assessment on each indicator can be seen in Table 2.

The indicators of destructive fishing, modification of fishing gear and fishing aids, fishing capacity and effort, and capture selectivity are worth 3 or based on green flag analysis which means a good status. Whereas, the compliance of the function and size of fishing vessels with legal documents and the certification of fishing vessel crews based on the regulations are in a red flag which means a bad status with a value of 1 as presented in Figure 1.

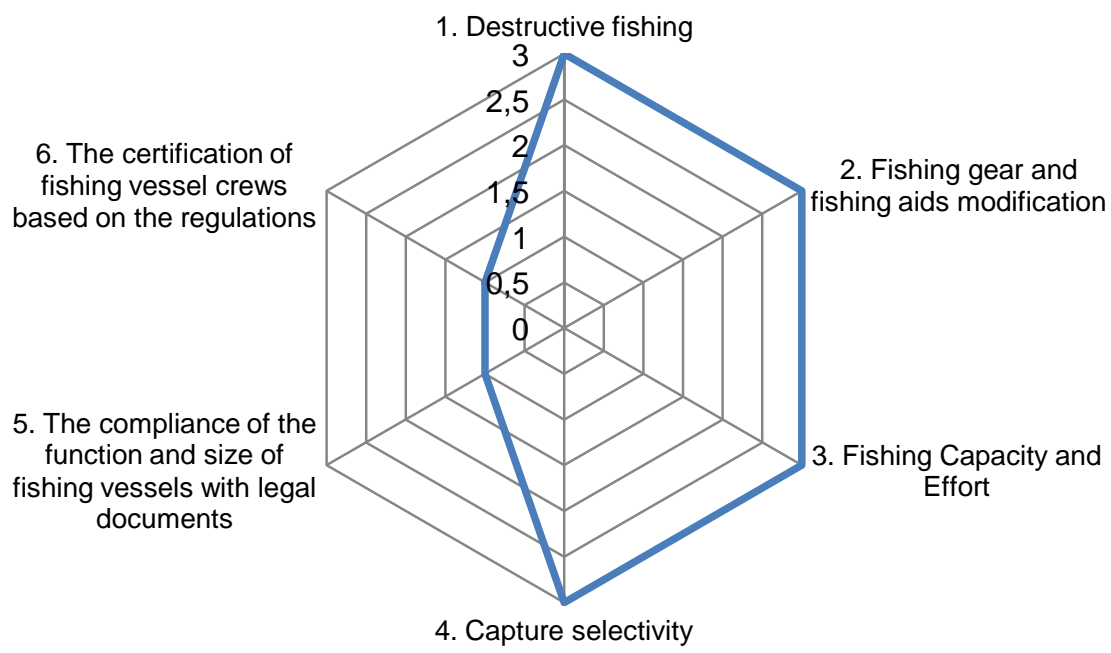

Figure 1 - The Graphic of Fishing Technique Domain Indicators

From Figure 1 above, it shows that the first, second, third and fourth indicators are important concerns. Meanwhile, the indicators that need further attention are the suitability of the function and size of the fishing vessels and the crew's certificate.

To improve these two indicators, it needs to conduct socialization activities to the public about the importance of having a certificate or legal documents for the fishing vessels and crews.

The action plan to maintain each indicator of fishing technique domain can be seen in Table 3 as follows.

Table 3 - The Action Plan for Improving the Fishing Technique Domain

\begin{tabular}{|c|c|c|c|c|c|c|c|c|c|c|c|c|c|c|c|c|}
\hline \multirow{3}{*}{ Indicator } & \multirow{3}{*}{$\begin{array}{c}\text { Year } \\
\text { Value } \\
0\end{array}$} & \multicolumn{15}{|c|}{ Maintenance Plan } \\
\hline & & \multicolumn{5}{|c|}{ Short-term (Year) } & \multicolumn{5}{|c|}{ Medium-term (Year) } & \multicolumn{5}{|c|}{ Long-term (Year) } \\
\hline & & 1 & 2 & 3 & 4 & 5 & 6 & 7 & 8 & 9 & 10 & 11 & 12 & 13 & 14 & 15 \\
\hline 1. Destructive fishing & 3 & 3 & 3 & 3 & 3 & 2 & 3 & 3 & 3 & 3 & 3 & 3 & 3 & 3 & 3 & 3 \\
\hline 2. Fishing gear and fishing aids modification & 3 & 3 & 3 & 3 & 3 & 3 & 3 & 3 & 3 & 3 & 3 & 3 & 3 & 3 & 3 & 3 \\
\hline 3. Fishing capacity and effort & 3 & 3 & 3 & 3 & 3 & 3 & 3 & 3 & 3 & 3 & 3 & 3 & 3 & 3 & 3 & 3 \\
\hline 4. Capture selectivity & 3 & 3 & 3 & 3 & 3 & 3 & 3 & 3 & 3 & 3 & 3 & 3 & 3 & 3 & 3 & 3 \\
\hline $\begin{array}{l}\text { 5. The compliance of the function and } \\
\text { size of fishing vessels with legal documents }\end{array}$ & 1 & 1 & 1 & 1 & 1 & 2 & 2 & 2 & 2 & 2 & 2 & 3 & 3 & 3 & 3 & 3 \\
\hline $\begin{array}{l}\text { 6. The certification of fishing vessel } \\
\text { crews based on the regulations. }\end{array}$ & 1 & 1 & 1 & 1 & 1 & 1 & 2 & 2 & 2 & 2 & 2 & 3 & 3 & 3 & 3 & 3 \\
\hline
\end{tabular}

Destructive fishing:

- It is hoped that the fishing in 1 to 15 years ahead will be good. By that, the Department of Marine and Fisheries is expected to conduct socialization to fishermen who carry out fishing activities to maintain a good shrimp catching so that the resources in the waters remain stable.

The modification of fishing gear and fishing aids: 
- In 1 to 15 years to come, it is expected that the Department of Marine and Fisheries will conduct socialization to fishermen who carry out fishing activities to maintain and not modify the fishing gear they use so that the resources in the water will be well maintained.

Fishing capacity and effort:

- In 1 to 15 years to come, it is expected that the fishing capacity and effort becomes better. The Department of Marine and Fisheries is suggested to conduct socialization to fishermen to maintain the fishing efforts. Therefore, the resources will remain sustainable.

Capture selectivity:

- In 1 to 15 years to come, it is recommended that the Department of Marine and Fisheries willing to conduct socialization to fishermen to keep using high selectivity fishing gear so that the resources in the waters will be well preserved.

The compliance of the function and size of fishing vessels with legal documents:

- In 1 to 5 years, a restoration will be carried out in accordance with the function and size of the ship;

- In 5 to 10 years, a corrective action plan needs to be done therefore the Department of Marine and Fisheries is expected to socialize and provide training that is related to the suitability of function and size of the ship. By that, the fishermen in South Sorong Regency can have a fishing permit;

- It is expected that the efforts in 10 to 15 years ahead will be good.

The certification of fishing vessel crews based on the regulations:

- In 1 to 5 years, a restoration for crew certification is done;

- In 5 to 10 years, a maintenance action plan is required. Therefore, the Department of Marine and Fisheries is expected to socialize and provide training concerning crew certification. As a result, the fishermen in South Sorong Regency can have a fishing certificate;

- The efforts in 10 to 15 years ahead are expected to be better.

\section{CONCLUSION AND RECOMMENDATIONS}

The analysis of EAFM composite index on the fishing technique domain in South Sorong Regency shows that destructive fishing for banana shrimp (Penaeus merguiensis) is in good condition with a green modeling flag and an average value of 3 . In this study, the indicator of fishing gear and fishing aids modification, fisheries capacity and effort, and capture selectivity is still in good status. Whereas, the indicators that have bad status and need to be prioritized in the future sustainable fisheries management are fishing with legal documents and fishing vessel crew certificates.

It needs an effort to improve the indicators which have a bad status such as fishing with legal documents and fishing vessel crew certificates. The effort can be done through socialization and an application of strict rules in fishing operations so that the fishery resources in South Sorong Regency will be well preserved.

\section{ACKNOWLEDGMENTS}

The researchers would like to thank the USAID SEA Project for the support and cooperation during the research to make this research completed successfully.

\section{REFERENCES}

1. Adrianto, L. M. (2005). Assessing Sustainability of Fisheries Systems In A Small Island Region. Proceedings of IIFET. . Tokyo: IIFET. 
2. Adrianto, L., Habibi, A., Fahruddin, A., Azizy, A., Susanti, H. A., Musthofa, I., et al. (2014). Modul Indikator untuk Pengelolaan Perikanan Dengan Pendekatan Ekosistem. Jakarta: Kementerian Kelautan dan Perikanan.

3. Dahuri, R. (2013). The blue future of Indonesia. Bogor: RODA Bahari.

4. Nazir, M. (2005). Metode Penelitian. Jakarta: Ghalia Indonesia.

5. Razak, A., Fahrizal, A., \& Irwanto, I. (2018). Status Pengelolaan Perikanan dengan Pendekatan Ekosistem (P3E) pada Domain Sumberdaya Ikan untuk Komoditas Udang di Kabupaten Sorong Selatan Provinsi Papua Barat. Jurnal Airaha, 7(02), 047-059.

6. Riduwan. (2004). Metode Riset. Jakarta: Rineka Cipta.

7. Subagyo, P. J. (2011). Metode Penelitian. Jakarta: Rineka Cipta.

8. Sururi, M., Mustasim, M., Hoek, F., \& Anasri, A. (2017). Laju Eksploitasi Sumberdaya Ikan Layang (Decapterus macrosoma) yang didaratkan di Pangkalan Pendaratan lkan (PPI) Kota Sorong-Papua Barat. Jurnal Airaha 6(1), 1-9.

9. USAID SEA Project. (2018). Laporan Enumerator. Sorong City: USAID SEA Project. 